Canadian Journal of Higher Education Revue canadienne d'enseignement supérieur

Volume 42, No. 2, 2012, pages 13-33

\title{
A 24/7 Public Possession: Understanding the Dissonance and Grace of Being a Post- Secondary Leader
}

Phil L. Davison

St. Francis Xavier University

\begin{abstract}
This study explores the perspectives and understandings of post-secondary leaders and their contexts as described through the qualitative experiences of 12 Maritime Canadian leaders (presidents and vice-presidents) who work in contemporary, publicly funded, post-secondary institutions. Four themes emerge: balancing daily dissonance, learning experientially to lead, creating learning spaces, and needing moments of grace. The research reveals that leaders seek deeper understandings of their work and their characterization.

\section{RÉSUMÉ}

Cette étude explore les perspectives et les connaissances de leaders en éducation postsecondaire et leurs contextes, tels que décrits par le biais des expériences qualitatives de 12 leaders (présidents et vice-présidents) canadiens des provinces des Maritimes qui œuvrent dans des établissements d'enseignement postsecondaires contemporains et publics. Quatre thèmes ressortent de l'étude : l'équilibre de la dissonance quotidienne, l'apprentissage expérimental pour devenir leader, la création de lieux d'apprentissage et le besoin de vivre des moments de grâce. La recherche révèle que les leaders aspirent à une compréhension plus approfondie de leur travail et de l'interprétation que l'on en fait.
\end{abstract}


Very little is known about how post-secondary leaders directly experience the contexts within which they work, and the few accounts that do exist are usually written by and about a single leader (Bok, 2003; Duderstadt, 2000). Further, explorations of how academic leaders construe and evaluate the differing discourses regarding post-secondary learning are limited. The literature suggests that post-secondary leaders are increasingly expected to balance facilitating learning and resisting corporate agendas regarding economically oriented outcomes of that learning, while also supporting academic freedom and scholarly inquiry (Clark, 2004; Fain, 2006; Iacobucci \& Tuohy, 2005; Olivieri, 2000; Slaughter and Rhoades, 2004; Washburn, 2005).

Certainly within contemporary United Kingdom and North American post-secondary discourses, there is a tendency to frame post-secondary learning using corporate, forprofit language (Armstrong \& Miller, 2006; Klaassen, 2000; Newman, Couturier, \& Scurry, 2004). Writers such as Franklin (2000), Morley (2003), Reynolds (1999), Tamburri (2007), Turk (2000), and academic associations in both the UK and North America argue that within such a business-oriented climate, learning in post-secondary institutions is under scrutiny by corporate and government interests to ensure that learning, and the institutions themselves, are accountable, competitive, profit focused, consumer driven, relevant to the workplace, and controlled by specified outcomes. Aronowitz (2000), Gouthro (2002), and Welton (2005) assert that while learning as a concept appears to have gained greater prominence in societal discourse, its actual role in society has changed from a historic focus on learning for citizenship and personal growth to learning for primarily socio-economic purposes. Others point to the contemporary mission, mandate, and values of higher education as contested domains (Bruneau \& Savage, 2000; Cervero \& Wilson, 2001; Tudiver, 1999) where post-secondary learning is treated as a global commodity. In this contested environment, corporate partners seek compromises and concessions from leaders and institutions regarding core academic values. Crowther (2004) suggests that the contemporary discourse of lifelong learning has become a mode of social control that serves as a "new disciplinary technology" (p. 125) to make people more compliant and adaptable for the workforce. Martin (2003) posits that the ongoing corporatization of institutions is compounded by the isolating and theoretical aspects of contemporary postsecondary life which does little "to raise such questions as urgent issues for democratic deliberation and debate, and to expand our notions of what it means to be active citizens in a democratized society" (p. 566). In such a guarded environment, the literature portrays academic leaders as increasingly wary about stepping forward to facilitate and/or lead any activity or initiative that may upset the corporate sector, especially since the bargaining power of business interests is dominant in university and college governance models and financing arrangements (Kirp, 2003; Readings, 1997; Sumner, 1999; Washburn, 2005).

Much is also written about how the changes in learning discourses within society and in post-secondary institutions reflect emerging corporate values (for example, Crowther, 2004; Geiger, 2004; Jarvis, 2001, 2006; Newman, Couturier, \& Scurry, 2004). One example of the corporate influence on academic leaders as portrayed in the literature is the President/CEO title that is becoming more common in community colleges, technical schools, and some universities in North America and the UK. Further, in many higher education journals and government policy documents, university leadership is increasingly described as "management"-a term that some critics view as not fitting the collabora- 
tive nature of leadership styles traditionally found in universities and colleges. Robertson (2000) points out that "the state and its policy making bureaucracy have encouraged the rise of the managerial class within universities and colleges-using the language, symbols and external trappings of the Chief Executive Officer" (p. 2). Further, in keeping with the transient nature of corporate CEOs, the average tenure of university and college presidents has decreased in the past two decades. Meanwhile, however, the responsibilities of the position have escalated (Fain, 2006; Williams, 2007).

One consistent conflict evident in the literature is the depiction of academic leaders as either visionary commanders or instruments of corporate sponsorship. Within some contemporary academic contexts, post-secondary leadership is dichotomized and thus seen, according to Robertson (2000),

as having a set of qualities superior in character to professional judgments on the welfare of students; or it is scorned as offering little that is consonant with the values and priorities of academic communities; or it is grafted uncritically and with varying degrees of conviction onto the body academic. (p. 1)

In addition, post-secondary leaders who encourage corporate funding are, in the view of some insider critics (faculty and academic associations), violating the basic tenets of academic freedom and scholarly inquiry. Graham (2000) sees two mindsets:

Scholarship and entrepreneurship are two different cultures, two different kinds of life: the life of the mind as opposed to the life of the bottom line. Some individuals manage to balance two such lives, but it is never easy: they risk turning a silk ear into a pig's purse. (p. 27)

However, the literature does not indicate if academic leaders themselves understand and express their experiences in such a dualistic manner-resisting and facilitating corporate research agendas while at the same time supporting academic freedom and scholarly inquiry. Further, it is not clear from the literature if leaders think that they are always at risk of turning a silk ear into a pig's purse every time they balance scholarship and entrepreneurship. In effect, we lack any information about how post-secondary leaders actually and frankly think about such discourses and goals.

Given this research gap, this question guided the study: What does it mean, in their own terms, for academic leaders to work in contemporary, public, post-secondary institutional contexts? Three subsidiary questions addressed overlapping dimensions of the leaders' work: (1) How do academic leaders experience and construe their everyday work, especially regarding how values, roles, and goals influence that activity? (2) How do academic leaders understand the contexts within which they work? (3) What challenges, resistances, and value-related conflicts, if any, within these contexts of their practice do they articulate? These questions were used to explicate the goals, roles, values, and challenges as expressed by academic leaders in publicly funded, post-secondary institutions.

\section{PARTICIPANTS AND INTERVIEW DATA COLLECTION}

Twelve academic leaders from public universities and colleges within Maritime Canada (comprising the Canadian provinces of Nova Scotia, New Brunswick, and Prince Ed- 
ward Island) accepted the invitation to participate in this research. Four participants had held their current position for less than two years; eight for six or more years. Two of the 12 leaders had retired recently and one was in transition. Three worked in community college settings; nine in universities. Three participants were women; nine were men. Although gender numbers are not balanced, they do approximate the overall ratio of women to men in Maritime Canada post-secondary leadership at the time of the study. Further, no racial diversity was possible since the regional leadership at that time of the study reflected only white backgrounds. However, such a mix of gender, geography, and institutional background brought a broad perspective to the study.

Data collection involved meeting with each leader for two in-depth interviews using only a few guiding questions (Johnson, 2002; Miller \& Glassner, 2004; Patton, 2001; Wengraf 2001). Interviews in the first round began with a broad question ("So tell me, what is it that you do?") to enable each interviewee to decide where to begin. Further questions flowed from what each interviewee said, making each interview a site of extreme concentration and a prompt for much post-interview note-taking. Interview times varied from one to two hours each with most averaging 90 minutes. Most of the firstround interviews occurred in the summer when many academic programs were not running; second-round interviews (based on analysis of first-round transcripts) were held approximately six months later. Overall, 16 interviews took place in leaders' offices; eight in other settings designated by the interviewee. All interviews were transcribed and the transcriptions returned to the leaders for review and comment before any data analysis. All of the leaders took the time to respond fully and frankly.

\section{DATA ANALYSIS}

Hermeneutic phenomenology (Gadamer, 1989) was used to interpret the data and consider the interpretive (hermeneutical) and the descriptive (phenomenological) aspects of the leaders' experiences and understandings. Thus, for this study, biographies of the leaders, an analysis of the post-secondary system, or a grounded theory of leadership were not required. Rather, it was necessary to gather the idiosyncratic understandings of what these leaders experience in their daily work and how this understanding compared with the research literature.

The iterative and cumulative analysis of the data followed five overlapping stages: organizing and coding the data; critically interpreting the data and identifying emerging meaning units and initial themes; analyzing the context within which the leadership experiences took place; winnowing of code categories; and more detailed analysis. Patterns and themes were viewed as building upon each other: where patterns are the commonalities evident across transcripts and where themes are more abstract and encompassing concepts to better represent how the patterns unify (Gadamer, 1989; van Manen, 1997). The formal stage of identifying patterns and themes took place once each set of interviews, transcripts, and codes was complete. But important to note here is that the patterns and themes that emerged from coding the first set of interviews were considered to be tentative and needing more exploration during and after the second set of interviews. Occasionally, patterns and theme qualities emerged during an interview since "arriving at themes can be the result of formal data analysis, but can be born from what was seen during the data collection" (Holliday, 2002, p. 104). For a detailed portrayal of the thematic 
elements including a composite portrayal of the interview data, the reader is encouraged to review "Between Dissonance and Grace: The Experiences of Post-Secondary Leaders" (Davison \& Burge, 2010).

\section{FOUR KEY THEMES}

Eight themes emerged initially, but four themes became clearer and stronger in their explanatory power: balancing daily dissonance, learning experientially to lead, creating learning spaces, and needing moments of grace. Within these themes that follow, I present the 12 leaders. They are Bailey, Kerry, Dominique, Amari, Drew, Dakota, Skyler, Devon, Jordan, Pat, Morgan, and Payton. The three women leaders are Jordan, Bailey, and Amari. The number 1 or 2 attached to the pseudonyms designates the first or second interview.

All leaders reviewed the four themes, and while there was the occasional divergence of perspective in other matters, their views were congruent regarding each theme description. Relevant transcript extracts illustrate the differing views and the rich qualities of their experience.

\section{Balancing daily dissonance}

Being a leader requires the constant balancing of dissonance: balancing the vision of the institution with the daily workload, balancing the professional elements of the job with the personal aspects of one's life, and balancing the historic expectations of the president as an academic with the contemporary role as chief executive officer (CEO). Leaders described this balancing as "stressful," "emotional," "all-encompassing," but also as "exciting," "exhilarating," and "addictive." There is a sense of constant movement as leaders describe balancing commitments across two seemingly dissonant ends of the spectra of daily experience.

For most leaders, the pace of their daily work is expressed as the numeric descriptor "24/7." They speak of "running as fast as you can" (Amari 1), being the president "all of the time, even in my private life" (Payton 1), and being "on-call always" (Morgan 2). Working such long hours is challenging both mentally and physically, as Amari (2) explains: "There is a high physicality to this job... which is ironic, given that you don't get to these jobs until you're older. It's a job for a 20-year-old body with a 60-year-old mind."

This perceived relentless demand for being always on duty comes from "multiple directions that... are set by the community, the institution, the faculty, the students, and other institutions" (Pat 2). Such constant, multi-directional pressure leaves leaders always exposed to public scrutiny where "people have their hooks in" (Kerry 1).

I hadn't realized when I came into this job how much of a public possession that I would be; and so I have refused to go past a certain point with how much [a public possession] I will be. I think it's important to have some corner of your existence that is private. (Bailey 1 )

Faced with such constant pressure of public exposure, the leaders use various ways to find their private time and space. Some "disappear for a few days" (Kerry 1) to take short vacations; others live away from the campus and use terms such as "sanctuary," "reflective space," or "isolated" to describe how their homes feel to them. Most have a home office, and they do try to contain their work there. Several adhere to a schedule that sees them 
arrive home at a specific time to eat with family and friends. But even in these private realms, the connections to their professional work world persist. Wireless laptops enable extensions of the home office space to other non-work spaces. Cell phones and electronic organizers carry phone calls and email messages into even the most private areas, with no regard for clock time: "There is a level of understanding about this position where the office is always present. You can't just shut it off whenever you feel like it” (Pat 2).

And yet, these leaders also believe that how and why they work as they do brings character, meaning, and purpose to their lives; they view their work more as a vocation than a paid job. Even as they lament their daily experience of dissonance and the sacrifice of personal space and time, they commit to vigour, perseverance, and loyalty regarding their institution's well-being and their leadership.

Finally, although leaders feel dissonance in balancing the roles and responsibilities associated with being the academic-as-CEO, all see benefits in a business-academe relationship despite the tensions inherent in such connections. The leaders understand the dissonant qualities between their CEO and academic roles, but they also acknowledge a responsibility to respond to the corporate discourse of change. And to make staff aware of such external demands on the institution, some leaders deliberately use business terminology to describe post-secondary education. For instance, for Skyler, managing the institutional context is more akin to running a business:

One of the things that I've done, for example, in meetings with the Senate is talk openly about markets for the institution and the marketing of the institution. Interestingly, nobody pushes back. It is as if that business language is now acceptable. (1)

Within such a business context, however, Skyler, like most of the leaders, thinks that traditional academic values are missing today. While the leaders do not suggest a return to the past, they do want a greater reflection of those traditional values in today's operations. Payton suggests that one way for presidents to restore such values is to be more involved in the educational matters of the institution:

I just did some consultancy work with several boards and they were banging on the table, "I want a president who brings in $x$ number of million dollars and who is out there earning money and establishing partnerships.” Well, I disagreed. I mean, "Like hell you do. Do you really want your president... only to bring in money?" One of the great things about some of the great presidents of the past is that they got to be involved in the learning that took place within the institution. (1)

\section{Learning experientially to lead}

This second theme encompasses those learning experiences gained by conducting daily activities, by being highly and publicly visible, by working with various internal and external constituencies, and, for the three women leaders, by managing some troubling dynamics born of gender-related issues.

When these leaders begin their job, they experience uncertainty in distinguishing "between what is really important and what is not," since what they might at first consider "to be minutiae may be in fact extraordinarily important to the organization" (Jordan 1). In addition, "everybody wants the president's ear and they want to put their opinion on 
the table before anyone else can" (Dominique 1). Leaders can feel overwhelmed trying to determine how their vision "might fit into the ambitions and plans of people lobbying their cause" (Dominique 1). Jordan reflects on the first year and concludes: "In your first year, you begin over a hundred different conversations" (Jordan 1). Therefore, part of the first year requires learning "who are the people to trust" (Skyler 2) and "which groups, especially external, should be front and centre and which you should be running away from" (Dominique 1).

Adding to the steepness of the learning curve are the collegial competitions for funding and enrolments and the 24/7 pace of daily work. Both factors make some leaders reticent to share their (self-acknowledged) learning needs with their Maritime peers. Jordan notes, "I find the learning piece hard and, to be honest, I miss the company of learning ... but for me to learn means taking a risk" (2). Even after the first few years on the job, leaders still consider their own formal learning to be a risk in terms of their status in relation to peers in the region. Jordan, for example, feels restricted:

You know, we can get trapped as CEOs. I've reached the top of my game. Where does a president go next? There is no real professional development for presidents. There is no real possibility to say "I need to learn something" because you are perceived as the boss after all. (1)

Jordan's feelings echo those of other leaders and suggest that this view of formal learning as a risk originates from increased contemporary internal and external demands: admitting to a knowledge "deficiency" could foster staff or public uncertainty in their leadership capacity.

Learning leadership only by direct experience includes learning to be the public face of the institution. "Well, wherever I go, I wear the logo pin and people ask me about the institution. So I can't escape this place, and I wear its logo not just physically but emotionally" (Amari 2). Being the living logo means being positive and crafting constructive and reassuring public statements for the "good of the institution" (Dakota 1) despite knowing all the internal difficulties. For example, when asked by other colleagues about institutional progress, Amari learned to respond with edited but strategic optimism:

When I first started the job and people would ask me how it was going, I would say, "Well, we have some enrolment problems and we have... and so on". I soon realized that people didn't really want to know this stuff.... There is a social convention to pretend that everything is going fine. So... you respond by saying "Just great"; that you're having a great year. (Amari 2)

In addition to learning to be managers of public messaging, leaders had to learn how to create a presidential persona and how to manage their ego. Leadership positions draw attention to self, and these leaders certainly understand the roles and limits of persona and ego in their work.

In essence, the president is portrayed as the embodiment of the institution.... Okay: so you know that is the context. However, if you are the kind of person who lets that stuff go to your head, you will inevitably be seen as shallow, arrogant, and egotistical. Further, if you behave as if you are above others, you will be thrown out.... You 
may, as a president, be asked to be a high flyer, associating with people who, and organizations that, can provide funding and/or research dollars to the institution. But if you start to act like a high flyer, your days are numbered. (Dominique 2)

Leaders know how a loss of contextual realism and/or a grounded self might easily occur "in all of the tasks and functions and trappings of the job" (Kerry 2). Such a loss may show up as an emperor-like, all-commanding style:

There is another change in people which occurs which I would label as the imperial mode. It's a standing observation ... about presidents in particular but also some vice-presidents. The longer they are in their jobs, the more imperial and imperious they become.... Frequently, the president who has changed in that way is vulnerable to making decisions and taking actions that they would have thought long and hard about [earlier]. (Skyler 2)

Finally, the three women leaders (Jordan, Bailey, and Amari) reflected on negative power relationships that women encounter as they learn to lead. One constraining perspective for these women is their observation from their own direct experience that many men do not always accord them respect for their intellectual skills solely because of their gender.

There are very few women in president and vice-president roles in this part of the country, and I think the gender issues are not explicit but more implicit.... Some men do not seem to take a woman seriously. (Jordan 1)

Bailey suggests that some staff within her institution seem to have very limited assumptions about her abilities and therefore create insulting situations:

Quite frankly, I think having a woman in a leadership position here has been a challenge for some people. There is almost an uncertainty regarding me around specific issues... like assuming that I cannot understand the budget, even though I am the president! (2)

Amari points to the frustrating naming and blaming games that persist even today within a predominantly male environment:

It's tough.... The problem is that if you are as assertive as the guys then you're considered to be bitchy. If you raise your voice, then you are hysterical or menopausal. If you are quiet, then you must be some kind of charlatan and shouldn't be doing the job. And if you behave differently, which women do, especially in a conversation, you are considered to be weak. So in many ways, you are damned if you do and damned if you don't. (2)

\section{Creating learning spaces}

All of the leaders explained what it meant for them to build engaged learning spaces that promote collegiality and trust. In such activity, however, they have to explain and negotiate sometimes conflicting constituent understandings of the purposes of post-secondary education. They have to respond to changing and often very pragmatic societal and institutional expectations, manage enrolment and finances within competitive contexts, 
and as much as is feasible, enhance staff and public confidence in the institution's relevance and integrity. They strive to protect the "organic, living, breathing entity" (Bailey 1), to foster spaces that "keep the community cohesive" (Jordan 1), and to create "respectful and professional learning spaces that are not at variance with scholarship and debate" (Drew 2). They learn that building such spaces requires them "to be in touch with people" since "the key to success is paying attention to the external and internal community" (Morgan 1).

One of the biggest perceived leadership challenges is managing the changing expectations voiced by internal and external constituencies. Needed is a response quite different from that given by the earlier generation of academic leaders.

Previously, I think that we had perhaps a kinder, gentler time. These were sleepier institutions. The competitive forces were not as great, the funding crunch wasn't as great, the public scrutiny wasn't as great. And so it was easier to just kind of plod along. But that context doesn't exist any longer. (Payton 1)

Competitive forces may offer dangerous opportunities to leaders: "the pressure to compromise, the pressure to take the easy way out rather than taking a stand" (Skyler 1). Leaders find themselves "colliding with issues with their own faculty, with the community, with government" (Skyler 1). Accountability emerges as a core institutional value, particularly for the university or college board.

Boards who feel more accountable to the community are putting more pressure on their presidents: they are firing them more frequently, asking for more from them. So there's something more going on than just what you or I may feel is a fair day's work. (Payton 1)

Leaders also believe that the current climate requires them to respond to students and parents who all position the student as customer or client with rights to services, standards, and compensation.

For example, a faculty member cancels several classes and the student then writes asking for his/her money back. The faculty member can't understand the student's request, but when you think about the costs of university courses that students and parents are paying, then the request becomes more understandable. So there are lots of challenges for presidents since we work within a context where, increasingly, a university education is viewed through consumer eyes. (Devon 2)

The final aspect evident in the theme of creating learning spaces centres on the absence of trust. The leaders understand this lack of trust as one of their greatest problems and thus work hard to create an institutional climate to foster trust. Trust is the key leadership element because "once you establish trust... everything works more easily" (Skyler 1). Leaders view the examples of distrust and cynicism within their institutions as originating from the fragmentation of the academic community, arising from disciplinary boundary effects and from peer-to-peer funding competitions. 
If you asked faculty members, "What is it that you do?" they would immediately begin with their discipline. That's fine, but I think that you must have other common goals in mind. That concept of common goals was the core defence of liberal education. There were things that transcended the individual disciplines so that, regardless of the discipline that you studied in, you came out with an enriched imagination and a variety of skills. (Skyler 1)

The key to developing trust is to "attend to and be in touch with people" (Morgan 1). Morgan kept in touch with people by sending handwritten notes to individuals internally and externally "who had significant things happen in their life." By taking time to write these notes, Morgan felt that the university community became richer and better integrated. Skyler worked at developing trust by building personal relationships.

In any large organization, the relationships can become purely professional ones. That can work I suppose, but I found that relationship model to be a very impoverished one. Having the ability to talk to people about family brings a different connection....If you develop strong relationships, then there is a culture of humanity in the institution. (Skyler 2)

\section{Needing moments of grace}

This fourth and final theme is seen to enrich leaders' daily work while also fostering a culture of institutional humanity. Moments of grace sustain leaders by giving them hope that they are making a difference and by reminding them of what is important in their daily work. Grace itself is construed as an experience (an event, activity, conversation) that produces a change in awareness of what it means experientially to be an academic leader. These moments carry elements and dynamics larger than themselves and deeper than those experiences encountered during everyday activity. In many ways, moments of grace also render tolerable the dissonance that leaders feel. Further, moments of grace may reveal aspects of their practice that require change or emphasis. These moments are unexpected, elusive, and always involve a connection with people. Payton calls them "touch points," Devon refers to them as "unexpected vignettes," and Skyler sees them as "little things." They are felt during convocation events, funerals, meetings with parents, interactions with faculty, and chance meetings with students.

They are those times in an organization where people are in awe of each other, in awe of what is before them, and in awe of the possibility. For me, it is always that sense of practice where you are trying to find that state of grace with the organization. [It is] a sense of coming together, a sense of movement which is sometimes very, very small. (Jordan 2)

Leaders cannot plan for a moment of grace. It is perhaps because they cannot control moments of grace or anticipate their occurrence that they have such an impact.

I remember, at one convocation ceremony, a woman... looked straight at me, and she said, "I want you to know that my family saved for two years so that I could take this program." Now I don't know what was going on in her mind that day, but... it 
was a great thing for someone in my position as president to hear such a statement and I have never forgotten that moment. (Payton 2)

Leaders can take steps to ensure that they are open to a possible grace occurrence. For instance, most leaders have an open-door policy, not for constant interruptions but for opportunities to experience the unexpected. Morgan and Bailey told of how students would often "just drop in to talk" and how the topics discussed often changed their perspective and understanding of their leadership role. Skyler described how his open-door policy and flexibility in meeting with faculty resulted in a trusting atmosphere. He reads a note from a faculty member:

As result of your tireless efforts, this place metamorphosed... into a happier place that made reasonable decisions where people could channel their energies to what drew them into the institution in the first place, namely teaching and research. Thank you for your role in making this place so much better.

Moments of grace are needed as reminders of aspects of leaders' work that need to be highlighted and/or changed. Leaders are sustained by the knowledge that their daily efforts and personal sacrifice is appreciated. They are transformed by an imaginative and often deeply personal awareness of what is possible.

\section{IMPLICATIONS FOR RESEARCH AND PRACTICE}

The findings carry implications for additional research and daily practice. These research and practice implications call for a broader examination of literature including that within the social and psychological domains. Four qualities of being a leader that emerged in the findings but that are not apparent in the literature warrant further research. These qualities are the dissonance between the personal and the professional parts of leaders' work, the challenges of learning experientially to lead while being alone and ahead (being out in front), the ethical congruence between job demands and individual values, and the formative experiences that shape leadership behaviour.

If no further research took place, then attention to the practical realm would be prudent. I offer seven suggestions.

1. Leaders seek spaces where they can share more openly their experiences with other leaders. Existing forums do not encourage such reflective conversation.

2. Leaders express an interest in having a mentored, experiential-learning program. Several possibilities include using retired leaders as mentors, pairing leaders from outside a geographical region with new and more experienced leaders inside the region, and having an online experiential learning forum.

3. Leaders want time for leisure and personal relationships outside of the institution. As Jordan notes, "Are we saying that somebody with a young family should not be eligible for these positions?" (Jordan 1).

4. Institutions might well consider gender and racial bias in academic leadership. This study did not explore gender or racial bias, but even the limited comments on gender offered by the women leaders show a system that continues to disadvantage them. Williams (2007), commenting on a study of American college and university leaders, notes, "The remarkable thing about the profile of the typical 
college president-a married, graying white man with a doctoral degree-is how little it has changed over the last 20 years" (p. 1). Certainly the fact that all of the leaders in this study (and all of Maritime Canada) are white bears critical analysis.

5. Leaders require opportunities to step back from their work and discuss with institutional staff and faculty the expectations of their leadership. Leaders feel that such open discussions could help foster collegial understanding and trust while also mitigating cynicism. Trust is seen as the most important aspect of their work and plays a crucial role in allowing them to carry out their work. Without trust, there is no possibility of negotiating what several leaders call "the great divide" that can sometimes exist between them and the faculty. Trust trumps secrecy, restores faith in the institution, and must coexist with dissent. For all of the leaders in this study, trust is the only currency that matters.

6. Leaders want to strengthen the mechanisms that bring institutional resources to bear on community problems. They seek to support efforts that move faculty and staff beyond the contemporary sense of entitlement and departmental fragmentation into a more collective awareness of community engagement and service. Further, they want to encourage and recognize faculty and staff who work to integrate community issues into the institutional vision. Such recognition efforts and models can help to foster trust and open dialogue both internally and externally. Leaders also want their boards to support them as they work to create learning spaces that deal with issues of civic importance.

7. Finally, leaders seek deeper understandings of their work and a richer portrayal of their characterization. The dichotomies evident in much of the literature and contemporary discourse do not reveal the nuance, complexity, poetics, and possibilities of their position. In the view of many of the leaders in this study, such portrayals foster institutional cynicism and may even erode the theoretical and practical communication pathways necessary for faculty, staff, and students to envision collective possibilities for a vibrant civil society.

\section{SIGNIFICANCE OF THE STUDY}

A key finding of this study as revealed in the literature (Bok, 2003; Kelly, 2007; Robertson, 2000) and echoed by the interviewees is that leaders' prior academic experience plays only a partial role in preparing them for their work as presidents and vice-presidents. While leaders note that critical thinking and writing skills are gained from their academic background, many of the skills needed for the job are garnered through experiential learning. As Amari notes, "The experiences of the job are like a PhD every year" (Amari 1). Leaders are expected to learn new skills such as finance, human resources, public speaking, and fundraising as quickly as they can and almost always in isolation. Most CEOs of large corporations would enter their jobs with training and experiences relevant for their position; however, academic leaders must draw upon experiential learning, formative experiences, and relationships with constituents to help them learn how to do their job. Commenting on the lack of appropriate formal training for post-secondary leaders, Kelly (2007) observes: “At least corporate executives have access to MBAs and associated training. What's available for university presidents?” (p. 3). 
The study also reveals how personal space and relationships are increasingly sacrificed to contemporary workplace demands. Leaders share the personal costs of having a job consigned to the exhausting requirement of always being out in front. They face intense public scrutiny from internal and external constituencies, many which have competing demands and expectations. Tamburri (2007) comments on the many competing demands placed on presidents, noting, "Life at the top has never been much of a picnic. But lately the challenges seem to have multiplied" (p. 30). Thus, what kind of leadership can institutions expect under such contemporary conditions? Further, is this the type of leadership that will sustain leaders and their institutions?

The interview findings demonstrate that leaders are critical of their own characterization in the literature (e.g., Aronowitz, 2000; Readings, 1997; Slaughter \& Rhoades, 2004), explaining that their work carries greater complexity than the implied dichotomies portray. They do not describe themselves as visionary commanders or instruments of corporate sponsorship. Instead, they talk of "being in service to the organization" (Jordan 1); of "working in partnership with faculty" (Pat 2); of "being a willow rather than the strong oak" (Dominique 1). Leaders argue that the contemporary leadership context requires deeper analysis; that they must move beyond elemental dichotomies that may result in a cynical view of leaders by faculty and staff. A deeper depiction that brings forward the dissonance and the grace of being a leader, that shows the dynamic, complex, and contradictory aspects of their daily experience would, in their view, strengthen the foundations of post-secondary education by adding new layers of meaning and experience to the literature of leadership.

Leaders also understand their essential role in protecting the dissenting and reflective spaces of academic institutions, but they believe that such spaces have limits defined by the many constituent understandings of learning and of academic leadership. Students and parents increasingly act as consumers, and board members, politicians, and members of the community call leaders to account for what takes place under the institutional rubric. Leaders see themselves "being on the hook" (Dominique 1) for institutional activities and argue that they face more intense public scrutiny than faculty and staff to mitigate the risk that may arise from expressed dissent. This finding supports the assertion in the literature that contemporary leaders work under structures and governance models that render difficult but not futile activist and critical leadership practices. That is, leaders suggest that being provocative in one's expression should occur only within the collective umbrella of institutional responsibility.

In addition to protecting the dissenting and reflective spaces of academic institutions (albeit within the limits mentioned), leaders feel that they must use their position to work with others in supporting learning spaces where lived integrity can flourish. As individuals, they understand "the power and privilege" (Jordan 1) of their role, but they also know that this power is not theirs; it belongs to the institution. Payton points out, "These positions cannot be defined by the people who hold them" (Payton 1). Essentially, leaders construe their work in terms of how the position transcends self and becomes connected to and part of a broader constituency; one that was there before they came and will continue to exist after they leave. Negotiating partnerships, raising funds, internationalizing the institution, creating more student-friendly places, and developing trust are several examples of how leaders expressed this aspect of supporting learning spaces. But there 
is something deeper that leaders desire-an aspect of their work that is connected to moments of grace and which seems a core component of a liberal arts education.

The interview findings allude to a sustaining place that goes beyond the often accidental and unpredictable qualities of daily work and experience (lifeworld) and extends into the more deliberate and continuous qualities of what this author calls lived integrity. The concept of lifeworld as portrayed in the literature (Gadamer, 1989; Habermas, 1989) does not adequately encompass lived integrity as it seems to be limited to immediate perceptions; however, this research suggests that there is something deeper in the way leaders understand their work or at least want to understand their work, especially as they deal with dissonance. Lived integrity is connected to lifeworld, but it carries greater integrative power as it threads through all the dynamics of daily life. In effect, lived integrity grows from what leaders learn during moments of grace and is shaped by the temporal, the emotional, the imaginative, and the spiritual- interestingly, all key elements of a liberal arts education. Although it exists on the fringes of perception, it is perceived as a foundational way of living with oneself that is both ontological and spiritual. It becomes, as noted by Payton, a personal "compass" that guides leaders and their work with the institution. It is described as "the fabric," "the glue," "the ethos," and "the experiential DNA" that holds leaders together. Without it, their lifeworld would fragment and succumb to cacophony. Further, it is perceived by the leaders as more than an essential personal attribute but also a necessary part of the collective post-secondary experience-an institutional fabric that they must help foster to connect people, encourage active citizenship, and support critical inquiry. Thus, the leaders strive to protect, grow, and sustain both personal and institutional lived integrity as a way to mitigate the daily dissonance of contemporary post-secondary life. And yet, they struggle to do so amid seemingly endless positional demands and relentless external institutional pressures from funders, partners, businesses, and communities that stretch and sometimes redefine personal and institutional lived integrity.

Leaders certainly acknowledge these pressures and note, for example, a greater acceptance of corporate language and values within their work. However, they do not understand these values as undermining traditional liberal arts values of citizenship and critical inquiry. They argue that such acceptance is a requirement of their work since partnerships and corporate funding are essential to the survival of the institution. Thus, the assertion in the literature that business partnerships create an increased acceptance of corporate language in the post-secondary environment is borne out in the research findings. Leaders note their own use of business language to describe institutional challenges and direction. While they temper such language with expressions of traditional civic engagement activities, they acknowledge that board members and external partners respond more immediately to corporate discourse than to academic discourse. Further, leaders do not seem to experience compromises of their values when using such discourse. Instead, they argue that such discourse fosters essential external partnerships and they believe that such partnerships "demonstrate the value proposition of the university at its best" (Kerry 1).

While most leaders do not portray the business community as an oppositional or hegemonic force and many spoke of the positive benefits of corporate partnerships, we might think more on why they hold such views. Perhaps the Maritime post-secondary context is still in the early stages of strong corporate involvement and the encroachment of business values has not yet delivered its full impact. To what extent might there be a corporate take- 
over of post-secondary institutions? Or are leaders already captured in the hegemonic grasp of the business community. Critics of this study might argue that leaders are not the most reliable witnesses to the force of corporate values. Their loyalty to the institution as a living entity could be construed as the leaders being proud guardians of the academy, rather than dispassionate critics of its evolution in today's economic realities. Further, we might ask how an increasingly corporate discourse and resulting values integrate with leaders' desired personal and institutional lived integrity. However, it is also possible that business and academic values may coexist with traditional post-secondary values under certain conditions and that leaders are working through evolutionary dissonance created in current contexts.

Muller noted in 1988 that presidents in contemporary institutions faced challenges not felt by an earlier cohort of leaders. Current literature and these research findings suggest that these challenges have only magnified in scale and grown more complex in operations. Institutions are larger. There are greater demands on leaders' time, greater demands to raise funds, greater requirements to be the "living logo" (Payton 1) of the institution. All these factors constrain leaders from finding more moments of grace and imaginative spaces. Leaders are challenged to "stay awake" (Payton 1) to possibility and transformation, but reflection occurs only sporadically within the cacophony of dissonance.

The findings suggest that leaders may be working through the evolution of an emerging leadership practice, one that seeks to integrate and recast traditional post-secondary education values within contemporary society. In this respect, the study offers hope that leaders and their institutions can continue to foster dissenting, trusting, and imaginative learning spaces that respect liberal arts traditions while also incorporating and questioning the possibilities of contemporary contexts, including corporate ones.

\section{UNDERSTANDING THE DISSONANCE AND GRACE OF BEING A POST-SECONDARY LEADER}

Van Manen (1997) reminds researchers, "A phenomenological text should never be read merely for its surface message.... In thoughtful phenomenological texts, the distinction between poetic and narrative is hard to draw" (p. 343). He accepts the notion, developed by Merleau-Ponty (1968), that phenomenology is inherently a poetizing activity that explores and speaks about experiences in an evocative and primal manner.

This research aimed to present a "thoughtful phenomenological [text]" by weaving the voices of the 12 participants within the thematic representations of the interview findings. However, to deepen this initial understanding of the experiences of leaders and to begin a broader conversation with others, I conclude this study with a poetic portrayal. Poetry integrates themes, qualities, and contexts from the leaders' accounts to provide a less dominating and a more relational space for both interviewees and the researcher while providing a richer hermeneutic text and a more transparent interpretation (Glesne, 1997; Riessman, 2003). To ensure that the poetic text did not stray from the lived experience of the leaders, I sent a copy to them. Every leader indicated that the poetic text captured the essence of their experience. Some even noted that the piece enhanced their understanding.

Dissonance and grace are two seemingly oppositional concepts, but they are inextricably linked inside the complexities, rewards, and relentless pressures of being a leader in today's post-secondary institutions. The following poem uses the leaders' words to capture the richness and results of those linkages.* 


\title{
The dissonance and grace of leadership
}

\author{
A 24/7 public possession \\ running as fast as I can \\ with hooks in me \\ Need a 20-year-old body \\ and 60-year-old mind \\ to avoid the cross-eyed vortex of minutiae \\ stay awake to the imaginative \\ and resist the flow \\ Can't be shackled by the past \\ Need to be five years out \\ connecting differently with bigger responsibility \\ More bloodhound than shepherd \\ because harmony \\ isn't without dissonance \\ Academic CEO \\ but not of sausage factory \\ because you must \\ protect the solitude \\ and hold fundamental values \\ honesty, integrity, fairness, caring for others \\ close \\ Learn by doing \\ it's the classic joke \\ All this education \\ and the job is ultimately experiential learning \\ Like a PhD every year \\ First year \\ sift agendas \\ learn whom to trust \\ and whom to run from \\ Begin a hundred different conversations \\ Go from strong oak to flexible willow \\ Avoid Imperial Mode
}


Then stand up as the living logo

Put best foot forward

Manage expectations

"How are things going?"

"Just great!"

Then awake at 3:00 a.m.

Better be right

Like a conductor

interpreting the original score

or master chess player

playing simultaneous games

with different rules

you engage the institution

You build a culture of humanity

with dissenting space

that "gets the people thing" right

Where values transcend disciplines

and students prepare for active citizenship

But changed societal realities

pressure compromise

Distrust and cynicism corrode

A zero-sum game

creates competition

bringing practical and vocational ambitions into prominence

Students become consumers

requesting refunds

"Is this going to be on the exam?"

Not the time to ape or mirror wider culture

Time to get back a sense of community

Reach across internal rifts

Transcend disciplines

Care deeply

Earn trust

In moments of grace

you bring people together

in relationship vignettes

where they appreciate

and are in awe

of each other 


\section{REFERENCES}

Armstrong, P., \& Miller, N. (2006). Whatever happened to social purpose? Adult educators' stories of political commitment and change. International Journal of Lifelong Education, 25(3), 291-305.

Aronowitz, S. (2000). The knowledge factory: Dismantling the corporate university and creating true higher learning. Boston: Beacon Press.

Bok, D. (2003). Universities in the marketplace: The commercialization of higher education. New Jersey: Princeton University Press.

Bruneau, W., \& Savage, D. (2000). Counting out the scholars: The case against performance indicators in higher education. Toronto, ON: Canadian Association of University Teachers, James Lorimer.

Cervero, R., \& Wilson, A. (2001). Power in practice: Adult education and the struggle for knowledge and power in society. San Francisco, CA: Jossey-Bass.

Clark, B. (2004). Sustaining change in universities: Continuities in case studies and concepts. Buckingham: Open University Press.

Crowther, J. (2004). "In and against" lifelong learning: Flexibility and the corrosion of character. International Journal of Lifelong Education, 23(2), 125-136.

Davison, P., and Burge, E. J. (2010). Between dissonance and grace: The experience of postsecondary leaders. International Journal of Lifelong Education, 29(1), 111-131.

Duderstadt, J. (2000). A university for the $21^{\text {st }}$ century. Michigan: University of Michigan Press.

Fain, P. (2006). Crisis of confidence. The Chronicle of Higher Education. Retrieved from http://chronicle.com/article/Crisis-of-Confidence/17094

Franklin, U. (2000). What is at stake? Universities in context. In J. Turk (Ed.), The corporate campus: Commercialization and the dangers to Canada's colleges and universities (pp. 17-21). Toronto: Canadian Association of University Teachers, James Lorimer.

Gadamer, H. G. (1989). Truth and method (J. Weinsheimer \& D. Marshall, Trans.) (2nd rev. ed.). New York: Continuum. (Original work published in 1960)

Geiger, R. (2004). Knowledge and money: Research universities and the paradox of the marketplace. Stanford, CA: Stanford University Press.

Glesne, C. (1997). That rare feeling: Re-presenting research through poetic transcription. Qualitative Inquiry, 3, 202-221.

Gouthro, P. (2002). Education for sale: At what cost? Lifelong learning and the marketplace. International Journal of Lifelong Education, 21(4), 334-346.

Graham, W. (2000). Academic freedom or commercial license? In J. Turk (Ed.), The corporate campus: Commercialization and the dangers to Canada's colleges and universities (pp. 23-30). Toronto, ON: Canadian Association of University Teachers, James Lorimer. 
Habermas, J. (1989). The structural transformation of the public sphere. Cambridge, MA: MIT Press.

Holliday, A. (2002). Doing and writing qualitative research. Thousand Oaks, CA: Sage.

Iacobucci, F., \& Tuohy, C. (2005). Taking public universities seriously. Toronto, ON: University of Toronto Press.

Jarvis, P. (2001). Universities and corporate universities: The higher learning industry in global society. London: Kogan Page.

Jarvis, P. (2006). Beyond the learning society: Globalization and the moral imperative for reflective social change. International Journal of Lifelong Education, 25(3), 201-211.

Johnson, J. (2002). In-depth interviewing. In J. Gubrium \& J. Holstein (Eds.), Handbook of interview research: Context and method (pp. 103-119). Thousand Oaks, CA: Sage.

Kelly, G. (2007). Fun at the top [Letter]. University Affairs, 48(5), 3. Ottawa, ON: Association of Universities and Colleges of Canada.

Kirp, D. (2003). Shakespeare, Einstein and the bottom line: The marketing of higher education. Cambridge, MA: Harvard University Press.

Klaassen, C. A. (2000). Empowerment and social responsibility in the learning society. In D. Wildemeersch, M. Finger, \& T. Jansen (Eds.), Adult education and social responsibility (2nd rev. ed., pp. 221-36). Frankfurt, Germany: Peter Lang.

Martin, I. (2003). Adult education, lifelong learning and citizenship: Some ifs and buts. International Journal of Lifelong Education, 22(6), 566-579.

Merleau-Ponty, M. (1968). The visible and the invisible (A. Lingis, Trans.). Evanston, IL: Northwestern University Press.

Miller, J., \& Glassner, B. (2004). The "inside" and the "outside": Finding realities in interviews. In D. Silverman (Ed.), Qualitative research: Theory, method and practice (2nd ed., pp. 125-139). Thousand Oaks, CA: Sage.

Morley, L. (2003). Quality and power in higher education. Buckingham: Open University Press.

Muller, S. (1988). The university presidency today: A word for the incumbents. In J. L. Fisher \& M.W. Tack (Eds.), New directions for higher education: Vol. 61. Leaders on leadership: The college presidency (pp. 23-29). San Francisco, CA: Jossey-Bass.

Newman, F., Couturier, L., \& Scurry, J. (2004). The future of higher education: Rhetoric, reality, and the risks of the market. San Francisco, CA: Jossey-Bass.

Olivieri, N. (2000). When money and truth collide. In J. Turk (Ed.), The corporate campus: Commercialization and the dangers to Canada's colleges and universities (pp. 53-62). Toronto: Canadian Association of University Teachers, James Lorimer.

Patton, M. (2001). Qualitative research and evaluation methods (3rd ed.). Thousand Oaks, CA: Sage.

Readings, B. (1997). The university in ruins. Cambridge, MA: Harvard University Press. 
Reynolds, M. (1999). Grasping the nettle: Possibilities and pitfalls of a critical management pedagogy. British Journal of Management, 1O(2), 171-184.

Riessman, C. (2003). Analysis of personal narratives. In J. Gubrium \& J. Holstein (Eds.), Inside interviewing: New lenses, new concerns (pp. 331-346). Thousand Oaks, CA: Sage.

Robertson, D. (2000). Educational leadership and management: Some consequences from tertiary-level institutions. Working Papers of the Global Colloquium on Supporting Lifelong Learning. Milton Keynes, UK: Open University. Retrieved from http://www. open.ac.uk/lifelong-learning/papers/39577600-oooE-7EoE-ooooo157000o0157.html

Slaughter, S., \& Rhoades, G. (2004). Academic capitalism and the new economy: Markets, state, and higher education. Baltimore, MD.: The Johns Hopkins University Press.

Sumner, J. (1999). Global vision or corporate nightmare? The privatization of adult education in the new millennium. Canadian Journal for the Study of Adult Education, 13(2), 73-85.

Tamburri, R. (2007). The evolving role of the president takes its toll. University Affairs, 48(3), 30-32.

Tudiver, N. (1999). Universities for sale: Resisting corporate control over Canadian higher education. Toronto, ON: Canadian Association of University Teachers, James Lorimer.

Turk, J. (2000). What commercialization means for education. In J. Turk (Ed.) The corporate campus: Commercialization and the dangers to Canada's colleges and universities (p. 3-13). Toronto: A Canadian Association of University Teachers title, James Lorimer \& Company Ltd.

van Manen, M. (1997). From meaning to method. Qualitative health research, 7(3), 345-369.

Washburn, J. (2005). University Inc.: The corporate corruption of American higher education. New York: Basic Books.

Welton, M. R. (2005). Designing the just learning society: A critical inquiry. Leicester: National Institute of Adult Continuing Education.

Wengraf, T. (2001). Qualitative research interviewing. Thousand Oaks, CA: Sage.

Williams, A. J. (2007, February 16). Presidents: Same look, different decade. The Chronicle of Higher Education, 53(24), A. 33.

\section{NOTE}

Some thematic elements in this current article appeared in the following document: Davison, P., \& Burge, E. J. (2010). Between dissonance and grace: The experience of postsecondary leaders. International Journal of Lifelong Education, 29(1), 111-131. 


\section{CONTACT INFORMATION}

Phil L. Davison

Director of the Extension Department

St. Francis Xavier University

Antigonish NS B2G 2W5

pdavison@ns.sympatico.ca

Phil Davison is fortunate to have worked and completed research in post-secondary and adult education for over 25 years in public, private, voluntary, and institutional settings. His range of experience includes leadership, private/public partnerships, asset-based community development, adult literacy, youth education, policy creation and evaluation, virtual learning, prior learning assessment recognition (PLAR), and strategic partnerships. He has held a variety of senior administrative positions in post-secondary institutions and government and is currently Director of Extension at St. Francis Xavier University in Antigonish, Nova Scotia, where he strives to secure the grace of his daily work. 